\title{
Multiple isotope tracers from Permian-Triassic hydrated sulfates: Implications for fluid-mineral interaction
}

\author{
Ana-Voica Bojar ${ }^{1,2, *}$, Stanislaw Hałas ${ }^{3 \dagger}$, Hans-Peter Bojar ${ }^{2}$ and Andrzej Trembaczowski ${ }^{3}$ \\ ${ }^{1}$ Department of Geography and Geology, Salzburg University, Hellbrunnerstrasse 34, 5020 Salzburg, Austria \\ 2 Centre of Natural History - Mineralogy, Universalmuseum Joanneum, Weinzöttlstraße 16, 8045 Graz, Austria \\ ${ }^{3}$ Mass Spectrometry Laboratory, Institute of Physics, Maria Curie-Skłodowska University, 20-031 Lublin, Poland
}

Received: 6 October 2018 / Accepted: 15 July 2019

\begin{abstract}
Isotopic compositions of water of crystallization and sulfate anionic group in gypsum and polyhalite were used as tracers for events related to their formation and subsequent evolution, as for example origin of crystallization water and extent of thermal overprint. For this purpose, gypsum and polyhalite from the Permo-Triassic evaporites of the Eastern Alps, were analysed for isotope composition of sulfate anionic group $\left(\delta^{34} \mathrm{~S}\right.$ and $\left.\delta^{18} \mathrm{O}_{\mathrm{SO} 4}\right)$ and water of crystallization $\left(\delta \mathrm{D}\right.$ and $\left.\delta^{18} \mathrm{O}\right)$. For comparison, water of crystallisation of polyhalite samples of similar age from New Mexico (USA), Kłodawa (Poland) and Hattberg, Hesse (Germany) were also investigated. Estimated $\delta^{18} \mathrm{O}$ and $\delta \mathrm{D}$ values of polyhalite formation brines vary from 14.4 to $3.4 \%$ and 42.5 to $-6.1 \%$, respectively. Gypsum formation brines show different $\delta^{18} \mathrm{O}$ and $\delta \mathrm{D}$ values, from -5.7 to $-15 \%$ and -30.9 to $-88.8 \%$, respectively. The measured $\delta^{18} \mathrm{O}_{\mathrm{SO} 4}$ values of sulfate group are compatible with a thermal overprint at $100^{\circ}-200^{\circ} \mathrm{C}$ for both minerals. The thermal overprint documented for the Eastern Alps led to gypsum but not to polyhalite dehydration. The isotopic composition of water of crystallization suggests that polyhalite is preserving the isotopic signature of an enriched brine. During a subsequent event, anhydrite rehydrated to gypsum, with the isotopic composition of water of crystallisation indicating lower ( $\delta \mathrm{D}$ and $\delta^{18} \mathrm{O}$ ) values than the present-day meteoric water ones. Due to their distinct mineral structure and, as a result, different temperature of dehydratation, gypsum and polyhalite record different histories following precipitation in an evaporative system.
\end{abstract}

Keywords: sulfates / water of crystallization / stable isotopes / Eastern Alps / Permian-Triassic

Résumé - Traceurs isotopiques multiples à partir de sulfates hydratés de Permien-Trias: implications pour l'interaction fluide-minéral. Les compositions isotopiques d'eau de cristallisation et des ions sulfate dans le gypse et la polyhalite ont été utilisées comme traceurs des événements liés à leur formation et à leur évolution ultérieure, comme par exemple l'origine de l'eau de cristallisation et de la surimpression thermique. À cette fin, le gypse et la polyhalite des évaporites permo-triassiques des Alpes orientales ont été analysés pour déterminer la composition isotopique des ions sulfate $\left(\delta^{34} \mathrm{~S}\right.$ et $\left.\delta^{18} \mathrm{O}_{\mathrm{SO} 4}\right)$ et de l'eau de cristallisation $\left(\delta \mathrm{D}\right.$ et $\left.\delta^{18} \mathrm{O}\right)$. À titre de comparaison, des eaux de cristallisation d'échantillons de polyhalite d'âge similaire du Nouveau-Mexique (États-Unis), Kłodawa (Pologne) et Hattberg, Hesse (Allemagne) ont également été étudiées. Les valeurs estimées du $\delta^{18} \mathrm{O}$ et du $\delta \mathrm{D}$ des saumures de formation de la polyhalite varient respectivement de 14,4 à 3,4\%o et de 42,5 à $-6,1 \%$. Les saumures de gypse présentent des valeurs de $\delta^{18} \mathrm{O}$ et $\delta \mathrm{D}$ différentes, de $-5,7$ à $-15 \%$ et de $-30,9$ à $-88,8$ respectivement. Les mesures de $\delta^{18} \mathrm{O}_{\mathrm{SO} 4}$ des ions sulfate sont compatibles avec une surimpression thermique à $100-200^{\circ} \mathrm{C}$ pour les deux minéraux. La surimpression thermique documentée pour les Alpes orientales a conduit au gypse mais pas à la déshydratation des polyhalites. La composition isotopique de l'eau de cristallisation suggère que la polyhalite préserve la signature isotopique d'une saumure enrichie isotopiquement. Au cours d'un événement ultérieur, l'anhydrite s'est réhydratée en gypse, la composition isotopique de l'eau de cristallisation indiquant

*Corresponding author: ana-voica.bojar@sbg.ac.at 
des valeurs inférieures $\left(\delta \mathrm{D}\right.$ et $\left.\delta^{18} \mathrm{O}\right)$ à celles de 1 'eau météorique actuelle. En raison de leur structure distincte et des résultats obtenus, différentes températures de déshydratation, du gypse et de la polyhalite, enregistrent différentes histoires après leur précipitation dans un système à évaporation.

Mots clés : sulfate / eau de cristallisation / isotopes stables / Alpes orientales / Permien-Trias

\section{Introduction}

Evaporites consist mostly of ionic salts containing the major ions $\mathrm{Na}^{+}, \mathrm{Ca}^{2+}, \mathrm{Mg}^{2+}, \mathrm{K}^{+}, \mathrm{Cl}^{-},\left(\mathrm{SO}_{4}\right)^{2-}$, and $\left(\mathrm{CO}_{3}\right)^{-2}$, structural water as well as other ionic constituents like $\mathrm{Ba}^{2+}$, $\mathrm{Sr}^{2+}, \mathrm{Br}^{-}, \mathrm{Li}^{+}, \mathrm{I}^{-}, \mathrm{B}^{3+}$. Approximately eighty different salt minerals have been identified for evaporite deposits, although only few of them are considered important rock formers (Holland, 1984). $\mathrm{MgSO}_{4}$ bearing marine evaporites are relatively rare in the geologic record and restricted to the late Precambrian, Pennsylvanian-Triassic, and Cenozoic (Eocene to modern) (Hardie, 1996). Generally, in evaporite deposits, minerals precipitate from sea water in reverse order of their solubilities: carbonates first, followed by sulfates, and finally chloride minerals. Polyhalite triple-cationic salt, $\mathrm{K}_{2} \mathrm{Ca}_{2} \mathrm{Mg}\left(\mathrm{SO}_{4}\right)_{4} 2 \mathrm{H}_{2} \mathrm{O}$, has a higher solubility than gypsum, polyhalite forming as near end member mineral in evaporite sequences, even after precipitation of halite.

Upper Permian potash-bearing rocks, including primary formed polyhalite and carnallite $\mathrm{KMgCl}_{3} 6 \mathrm{H}_{2} \mathrm{O}$, are found in the Delaware basin in the western Texas and south-eastern New Mexico (Lowenstein, 1988; Barker and Austin, 1993) as well as in NE England (Armstrong et al., 1951; Kemp et al., 2016) and the Zechstein basin of Germany (Kampschulte et al., 1998). The origin of polyhalite of Permian age from the Zdrada platform and Peribaltic Basin of Poland was investigated by Peryt et al. (1998) and Peryt et al. (2005), the authors concluding that it formed by reaction of anhydrite with marine brines. By determining the age of polyhalite by ${ }^{40} \mathrm{Ar} /{ }^{39} \mathrm{Ar}$ method, Schorn et al. (2013) and Leitner et al. (2013) linked tectonic events and mineral textures from the Northern Calcareous Alps.

Recently, formed diagenetic polyhalites replacing gypsum or anhydrite were investigated from Baja California, Mexico (Holser, 1966). Polyhalite may form as a back reaction between brine and glauberite $\mathrm{Na}_{2} \mathrm{Ca}\left(\mathrm{SO}_{4}\right)_{2}$, as demonstrated for the drill holes from the Lop Nor basin, China (Ma et al., 2010). Polyhalite occurs as end member precipitate in a recent playa lake of La Mancha, Spain (Pena et al., 1982) or in the evaporitic sequence of the Salt Lake, Tuz Gölü basin, Turkey (Camur and Mutulu, 1996). Potash salts, including polyhalite, form today also in the Qaidam basin, China (Lowenstein et al., 1989) or Sambhar Lake, Thar Desert, India (Sinha and Raymahashay, 2004).

Once formed, gypsum and polyhalite record in their texture or isotopic composition primary and/or secondary events, the last ones occurring much latter than their formation age. For example, for the Carpathian Foredeep, Hałas and Krouse (1982) investigated for Miocene gypsum the isotopic composition of water of crystallization and demonstrated that during the last glacial, isotopically depleted meteoric water was incorporated in gypsum as water of crystallization.
Matsubaya and Sakai (1973) demonstrate that anhydrites and gypsum were rehydrated subsequently by various mechanisms. By using a different method, namely the ${ }^{40} \mathrm{Ar} /{ }^{39} \mathrm{Ar}$ dating, Leitner et al. (2013) conclude that the radiogenic system of Permian polyhalites from the Eastern Alps is not recording formation ages but subsequent Permian and Alpine events.

In the present study, we investigate mineral formation and subsequent events recorded in hydrated sulfates deposits by using multiple isotope systems recorded in the sulfate anionic group and water of crystallization. The investigated minerals are: gypsum and polyhalite of Upper Permian and Triassic age from the most prominent evaporitic sequences of the Alps and, in order to compare the effect of contrasting thermal history on the isotope composition of water of crystallization, selected samples from New Mexico (USA) and Kłodawa mine (Poland) and Hattberg, Hesse (Germany).

\section{Geological setting}

Sulfates occur in the halite and gypsum deposits of the Northern Calcareous Alps and in the so-called Central Alpine Mesozoic (Fig. 1). The two units of the Eastern Alps are characterised by the presence of representative and well exposed Permian-Triassic evaporitic deposits (Schorn et al., 2013; Leitner et al., 2013). Description of samples from various locations, mineralogy, texture as well as the age of the deposits are given in the supplementary material. Systematic presentation of the mineral deposits is given in Bojar et al. (2016).

Additionally, we analysed two polyhalites from New Mexico (Barker and Austin, 1993). Two others polyhalite samples are from the Zechstein facies of Europe, namely one from the Kłodawa Mine, Poland (Burliga, 2014) and the other from Hattdorf, Hesse, Germany (Kampschulte et al., 1998).

\section{Analytical methods}

The stable isotope data of sulfates were obtained on a dual inlet and triple collector mass spectrometer on $\mathrm{SO}_{2}$ prepared from the supplied $\mathrm{BaSO}_{4}$ samples by the method published by Hałas and Szaran (2001) in the case of $\delta^{34} \mathrm{~S}$ measurements, and on $\mathrm{CO}_{2}$ prepared from these $\mathrm{BaSO}_{4}$ samples by the method of Hałas et al. (2007) in the case of $\delta^{18} \mathrm{O}_{\mathrm{SO} 4}$ measurements. NBS127 was used as internal standard. Results are reported with respect to the international standards Canyon Diablo Troilite (V-CDT) and Standard Mean Ocean Water (V-SMOW), respectively, with standard deviation better than $\pm 0.2 \%$.

Water of crystallization was extracted by heating the samples in vacuum. Firstly, the samples were treated in vacuum by heating at $50^{\circ} \mathrm{C}$ for two hours in order to remove 


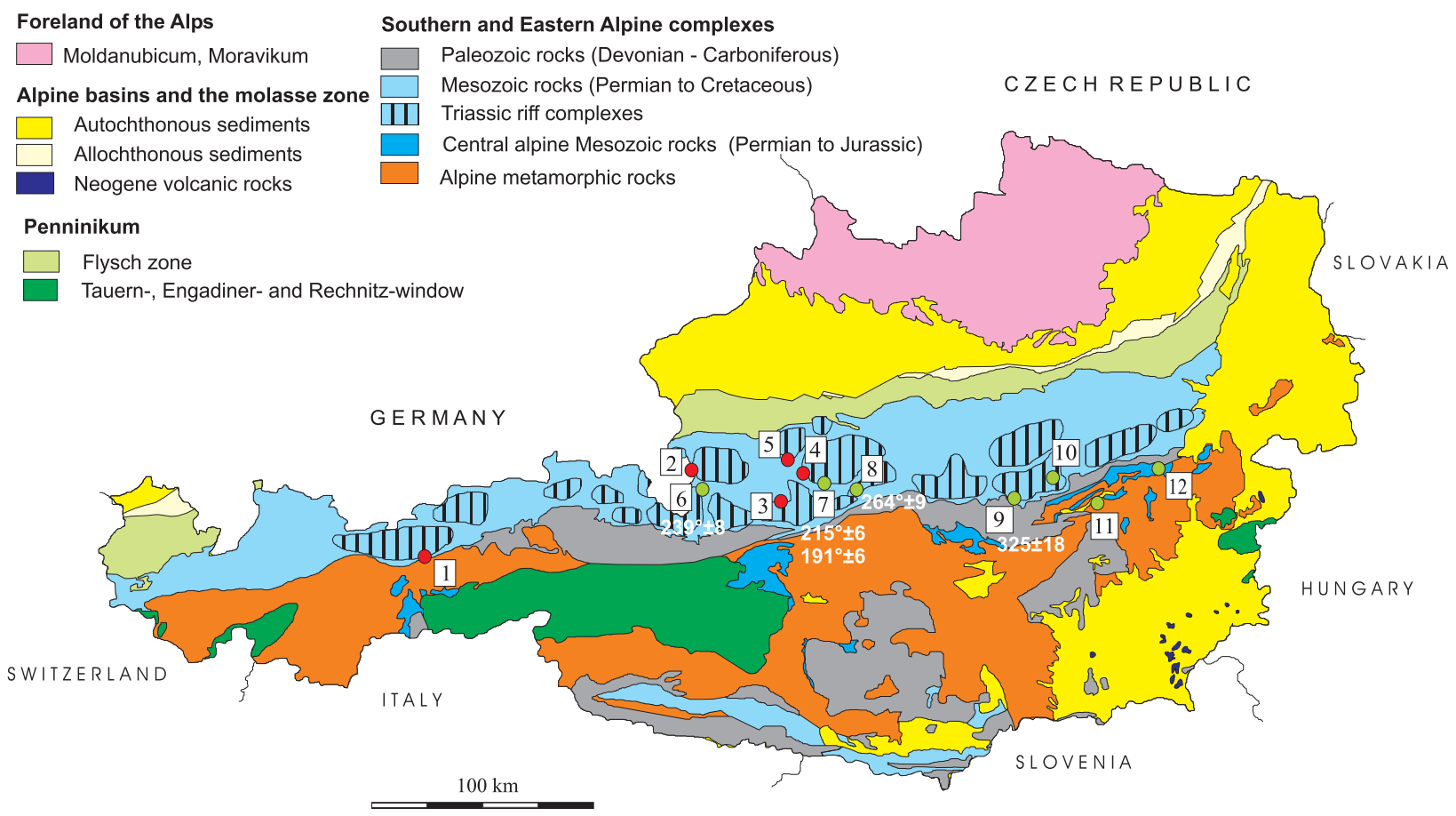

Fig. 1. Geological overview of the Eastern Alps showing the distribution of investigated sulfates. Salt: 1-Hall in Tirol, 2-Hallein, 3-Hallstatt, 4Altaussee, 5-Bad Ischl; Gypsum deposits, Northern Calcareous Alps: 6-Golling, 7-Wienern, 8-Lessern, 9-Tragöß, 10-Seewiesen; Gypsum deposits, Central Alpine Mesozoic: 11-Stanz, 12-Göstritz. Overprint temperature of sulfates were calculated using sulfur isotope thermometer (Bojar et al., 2016).

absorption water (Hałas and Krouse, 1982). Crystallization water was than collected by heating gypsum at $250{ }^{\circ} \mathrm{C}$ and polyhalite at $400{ }^{\circ} \mathrm{C}$. The cryogenically trapped water was subsequently analysed for $\delta^{18} \mathrm{O}$ and $\delta \mathrm{D}$ on a Picarro L2120-i Analyzer. Laboratory standards, previously calibrated to the VSMOW-VSLAP scale were OH-13 $\left(\delta \mathrm{D}=-2.84 \%\right.$, $\delta{ }^{18} \mathrm{O}=$ $-0.96 \%)$ and $\mathrm{OH}-16\left(\delta \mathrm{D}=-114.68 \%, \delta \delta^{18} \mathrm{O}=-15.43 \%\right.$ ) (Bojar et al., 2017). These standards were used to normalize the results to the V-SMOW-V-SLAP scale. The isotopic compositions of water of crystallization were synchronously measured, with a standard deviation of $\pm 0.1 \%$ for $\delta^{18} \mathrm{O}$ and $\pm 0.4 \%$ for $\delta \mathrm{D}$.

\section{Results and Interpretation}

\subsection{Results}

For the present study, the measured $\delta^{34} \mathrm{~S}$ and $\delta^{18} \mathrm{O}$ values of sulfates and $\delta^{18} \mathrm{O}$ and $\delta \mathrm{D}$ of water of crystallization are given in Tables 1 and 2, respectively. For the Northern Calcareous Alps, $\delta^{34} \mathrm{~S}$ values for both gypsum and polyhalite of Late Permian age, fall in a narrow range between 10 and 13\%o, except one sample with 14\%o (Tab. 1). Triassic (Carnian-Norian) sulfates from the Central Alpine Mesozoic, consistently show a more enriched isotopic composition, with $\delta^{34} \mathrm{~S}$ values between 14 and $15 \%$. In contrast to sulfur, the $\delta^{18} \mathrm{O}_{\mathrm{SO} 4}$ values of gypsum and polyhalite show a broader distribution between 12 and 20\%o, with one exception (H_5) showing 6.5\%o (Tab. 1).

The $\delta^{18} \mathrm{O}$ and $\delta \mathrm{D}$ values from gypsum crystallisation water vary from -1.8 to $-11.1 \%$ and from -50.3 to $-107 \%$, respectively (Tab. 2). Polyhalite $\delta^{18} \mathrm{O}$ and $\delta \mathrm{D}$ values vary from 13.3 to $7.4 \%$ and from -1.2 to $-26 \%$, respectively.
Table 1. Isotopic composition of sulfates for which water of crystallization was measured.

\begin{tabular}{llll}
\hline Sample & Mineral & $\begin{array}{l}\delta^{34} \text { S sulfates } \\
\text { (V-CDT) }\end{array}$ & $\begin{array}{l}\delta^{18} \text { O sulfates } \\
\text { (V-SMOW) }\end{array}$ \\
\hline Salt, NCA & & & \\
*HT_2, Hall in Tyrol & Gypsum & 10.2 & 13.1 \\
D_4, Hallein & Polyhalite & 13.1 & 13.6 \\
D_2, Hallein & Polyhalite & 11.6 & 17.8 \\
*H_4, Hallstatt & Gypsum & 10.4 & 14.5 \\
*H_1, Hallstatt & Polyhalite & 10.3 & 16.0 \\
H_5, Hallstatt & Polyhalite & 10.0 & 6.2 \\
*A_5, Altausee & Gypsum & 12.7 & 17.1 \\
*A_1, Altaussee & Polyhalite & 11.5 & 18.8 \\
A_6, Altaussee & Polyhalite & 11.2 & 14.8 \\
BI_3, Bad Ischl & Polyhalite & 10.3 & 13.9 \\
Gypsum, NCA & & & \\
*G_4, Golling & Gypsum & 11.7 & 19.8 \\
*W_9, Wienern & Gypsum & 11.1 & 14.7 \\
*T_8, Tragöss & Gypsum & 14.0 & 11.5 \\
*WD_1, Seewiesen & Gypsum & 11.3 & 14.9 \\
*WD_2, Seewiesen & Gypsum & 11.3 & 14.3 \\
Gypsum, CAM & & & \\
*GT_2,Göstritz & Gypsum & 15.5 & 15.6 \\
*GT_4, Göstritz & Gypsum & 15.1 & 20.8 \\
*ST_2, Stanz & Gypsum & 14.2 & 14.7 \\
\hline
\end{tabular}

The samples with an asterisk are from Bojar et al., 2016. 
Table 2. Isotopic composition of water of crystallization and brine.

\begin{tabular}{|c|c|c|c|c|c|c|}
\hline Sample & $\begin{array}{l}\text { Altitude } \\
\text { (m) }\end{array}$ & Mineral & $\begin{array}{l}\delta^{18} \mathrm{O} \text { crystallization } \\
\text { water }(\mathrm{V}-\mathrm{SMOW})\end{array}$ & $\begin{array}{l}\delta \mathrm{D} \text { crystallization } \\
\text { water }(\mathrm{V}-\mathrm{SMOW})\end{array}$ & $\begin{array}{l}\delta^{18} \mathrm{O} \text { brine } \\
(\mathrm{V}-\mathrm{SMOW})\end{array}$ & $\begin{array}{l}\delta \mathrm{D} \\
\text { brine }(\mathrm{V}-\mathrm{SMOW})\end{array}$ \\
\hline \multicolumn{7}{|l|}{ Salt, NCA } \\
\hline D_4, Hallein & 450 & Polyhalite & 7.4 & -26.0 & 3.4 & -6.1 \\
\hline D_2, Hallein & 450 & Polyhalite & 10.1 & -10.0 & 6.0 & 10.3 \\
\hline H_5, Hallstatt & 510 & Polyhalite & 10.4 & 4.7 & 6.4 & 25.2 \\
\hline A_5, Altausee & 710 & Gypsum & -7.2 & -91.7 & -11.1 & -73.2 \\
\hline A_1, Altaussee & 710 & Polyhalite & 13.3 & -3.0 & 9.3 & 17.3 \\
\hline A_6, Altaussee & 710 & Polyhalite & 12.8 & 1.9 & 8.7 & 22.3 \\
\hline BI_3, Bad Ischl & 470 & Polyhalite & 12.4 & 8.7 & 8.4 & 29.3 \\
\hline WD_1, Seewiesen & 970 & Gypsum & -10.9 & -89.8 & -14.8 & -71.2 \\
\hline WD_2, Seewiesen & 970 & Gypsum & -9.2 & -96.4 & -13.2 & -78.0 \\
\hline \multicolumn{7}{|l|}{ Gypsum, CAM } \\
\hline GT_2,Göstritz & 800 & Gypsum & -9.5 & -93.2 & -13.5 & -74.7 \\
\hline GT_4, Göstritz & 800 & Gypsum & -9.3 & -92.1 & -13.3 & -73.5 \\
\hline ST_2, Stanz & 650 & Gypsum & -11.0 & -107.0 & -14.9 & -88.8 \\
\hline NM1, New Mexico, USA & 1100 & Polyhalite & 13.4 & 5.2 & 9.36 & 25.7 \\
\hline NM2, New Mexico, USA & 1100 & Polyhalite & 18.44 & 21.6 & 14.38 & 42.5 \\
\hline K1, Kłodawa Mine, Poland & 100 & Polyhalite & 14.9 & 16.1 & 10.81 & 36.9 \\
\hline
\end{tabular}

\subsection{Interpretation}

\subsubsection{Isotopic fractionation between hydrated salts and water}

\subsubsection{Fractionation between water of crystallisation in gypsum and brine}

According to Gonfianti and Fontes (1963), the fractionation factor for oxygen is $\alpha=1.0037$; Fontes and Gonfiantini (1967) determined the fractionation factor for hydrogen as $\alpha=0.98$, both fractionation factors being not temperaturedependent.

For gypsum, a summary of available fractionation factors between oxygen in brine and oxygen in water of crystallization is given by Herwartz et al. (2017). The authors also determined a fractionation factor of 1.0034 , but used for their calculations the factor of 1.0037 as determined by Gonfianti and Fontes (1963). Herwartz et al. (2017) mention that by using one of the already determined factors of 1.0034 to 1.004 the calculated oxygen composition of brines will not significantly change. Concerning hydrogen, Gazquez et al. (2017) determined a fractionation factor in good agreement to Fontes and Gonfiantini (1968). In the present case, the small temperature dependence found by Gazquez et al. (2017) does not change our interpretation. The fractionations of Gonfianti and Fontes (1963) and Fontes and Gonfiantini (1967) approximate better the present situation where we have not precise constrains for temperature.

\subsubsection{Fractionation between water of crystallisation in polyhalite and brine}

Hydrogen isotope fractionation between hydroxyl bearing minerals and water is for most of the determined minerals less than 1 (Chako et al., 2001 and reference therein). It has been shown that salt hydrates crystallization causes deuterium enrichment of brine (Barrer and Denny, 1964; Horita, 1989). For sulfate bearing minerals, both hydrogen from the hydroxyl group as well as from water of crystallization are deuterium depleted in respect to brine (Seal et al., 2000). The hydrogen isotopic fractionation of crystallization water for the complex polyhalite structure is not precisely determined. If we consider a fractionation factor less than one, for example in the range determined for alunite-jarosite for the hydroxyl group (Seal et al., 2000), than the calculated values of brines in the present study will not change in order to affect conclusions. The fractionation factor for hydrogen in gypsum $(\alpha=0.98)$ is between those determined for structural water in alunite $(\alpha=1.004)$ and jarosite $(\alpha=0.050)$. The number of determined ${ }^{18} \mathrm{O}$ fractionation for salt hydrates are even smaller (Horita, 1989; Seal et al., 2000) and in the order of magnitude of this 


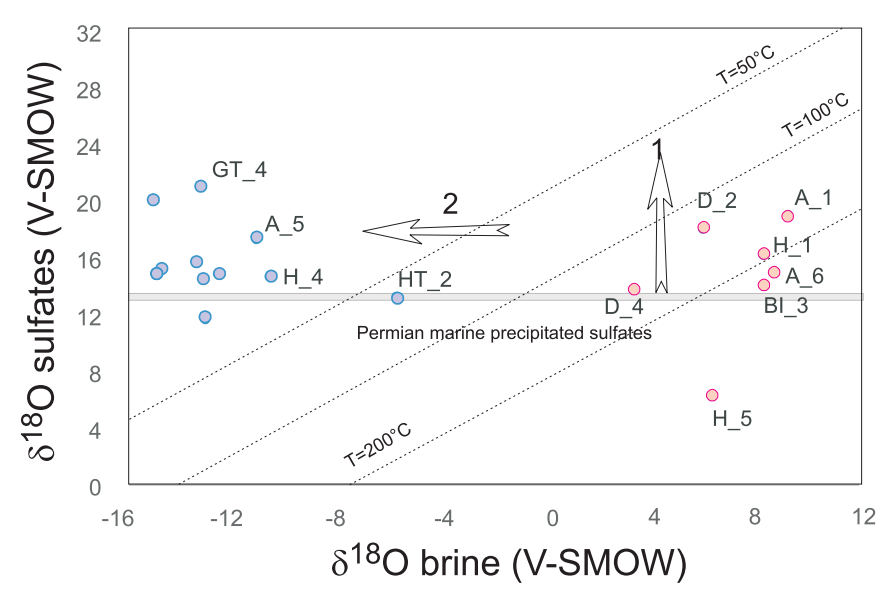

Fig. 2. Plot of $\delta^{18} \mathrm{O}$ of brines versus $\delta^{18} \mathrm{O}_{\mathrm{SO} 4}$ for the investigated sulfates: blue dots represent gypsum and red polyhalite isotopic compositions. "Trend 1" indicates the thermal event affecting both anhydrite/gypsum and polyhalite $\delta^{18} \mathrm{O}_{\mathrm{SO} 4}$ : "trend 2" shows that subsequently crystallization water of gypsum was replaced by meteoric water at low temperature. $\delta^{18} \mathrm{O}_{\mathrm{SO} 4}$ values are the same range for both minerals, gypsum and polyhalite, suggesting that thermal overprint shown by "trend 1" affected both to similar extent. Isotherm calculation was done according to Zeebe (2010). Blue horizontal line represents Permian oxygen isotopic composition in sulfates precipitated from seawater.

determined for gypsum. According to the reasoning, we consider for polyhalite the fractionation factors as for crystallization water in gypsum and calculated the values for brines as displayed in Figures 2 and 3.

\subsubsection{Calculated isotopic composition of brines from the measured water of crystallisations in gypsum and polyhalite}

Using the Gonfianti and Fontes (1963) fractionation factors for oxygen $(\alpha=1.0037)$ and Fontes and Gonfiantini (1967) for hydrogen $(\alpha=0.98)$, the calculated isotopic compositions of brines are shown in Table 2 . The equation for the fractionation factor is given by $\alpha=\left(1000+\delta_{\text {water }}\right.$ crystallisation $) /\left(1000+\delta_{\text {brine }}\right)$. For gypsum, the $\delta^{18} \mathrm{O}$ and $\delta \mathrm{D}$ values of brines vary from -5.7 to $-15 \%$ and from -30.9 to $-88.8 \%$, respectively. For polyhalite, the $\delta^{18} \mathrm{O}$ and $\delta \mathrm{D}$ values of brines vary from 14.4 to $3.4 \%$ and 42.5 to $-6.1 \%$, respectively (Tab. 2).

\section{Discussion}

As temperature of dehydration is important for the interpretation of the results, data regarding this aspect will be discussed in the following paragraph for the two investigated minerals, gypsum and polyhalite.

\subsection{Dehydration temperature of gypsum and polyhalite}

Polyhalite loses crystallization water at approximately $285^{\circ} \mathrm{C}$ (Fisher et al., 1996), its structure being more stable than

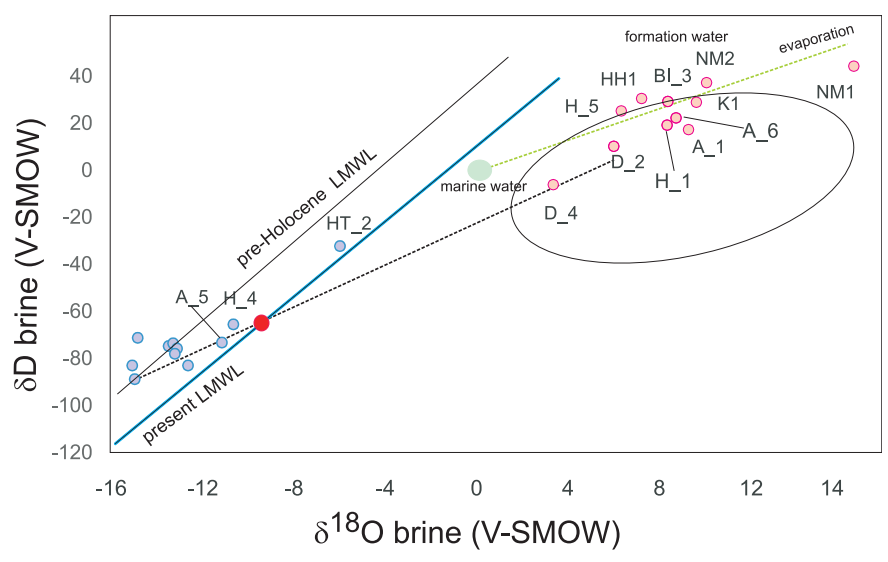

Fig. 3. Plot of $\delta D$ versus $\delta^{18} \mathrm{O}$ of brines (blue dots: gypsum crystallization waters; pink dots: polyhalite crystallization waters). The ellipse is displaying the field of syngenetic brines from the Kłodawa salt mine (for details see Dulinski et al., 2014). Other elements displayed are: Permian ocean water isotopic composition similar with the present one, Knauth and Beeunas (1986); the present Local Meteoric Water Line (LMWL); the mean $\delta^{18} \mathrm{O}$ value of the present day precipitation (red circle); the pre-Holocene meteoric water line showing a similar slope to the present day but with $\delta^{18} \mathrm{O}$ mean values with c. $3 \%$ lower; LMWL data according to the IAEA database for the Klagenfurt airport station (IAEA database, 2010), the red point from the LMWL represents the mean value.

that of gypsum, which loses crystallization water at $200^{\circ} \mathrm{C}$ (Kemp, 1999). According to Wollmann et al. (2008), polyhalite dehydration starts at $\sim 255^{\circ} \mathrm{C}$, the reaction being completed at $\sim 343{ }^{\circ} \mathrm{C}$. Polyhalite precipitates from saturated solutions at more elevated temperature than normal laboratory conditions of $\sim 20^{\circ} \mathrm{C}$, increase of temperature to boiling driving crystallization (D'Ans, 1908). In this context, we consider that temperature of polyhalite crystallization is an additional factor for determining the geological time-period when polyhalite mineral deposits formed. For example, large volumes of polyhalite are known for Permian. In addition to the sulfate-rich oceans present at that time, brine temperatures around $50^{\circ} \mathrm{C}$ (Hałas et al., 2015) may have further enhanced the formation of the mineral.

\subsection{Isotopic composition of sulfur and oxygen in the sulfate group; extent of thermal overprint}

Sulfur isotope chemostratigraphy curve constructed with sulfates recovered from marine evaporites and marine carbonate deposits were for example constructed by Claypool et al. (1980), Kampschulte et al. (1998), Paytan and Gray (2012), Sial et al. (2015). The sulfur isotope data from Tab. 2 suggest that sulfates largely preserve their initial marine sulfur isotopic composition, a discussion for the Alpine realm is included for example in Longinelli and Flora (2007), Boschetti et al. (2011), Bojar et al. (2016) and references inside.

According to Longinelli (1983), the oxygen isotopic composition of marine present-day precipitated sulfates is $13 \%$, similar with the Permian one as determined for exemple by Boschetti et al. (2011); Bojar et al. (2016) (Fig. 2). For 
sulfates precipitated at ambient temperatures, the measured oxygen isotope composition is largely in disequilibrium with the oxygen isotope composition of water (Chiba and Sakai, 1985). Hałas and Pluta (2000) demonstrate that in the case of long residence time, the isotopic re-equilibration process between oxygen in gypsum sulfate group and oxygen in water molecules of brines may start at temperatures of $30-35^{\circ} \mathrm{C}$, their findings being in accordance with Zeebe (2010). For isotherms calculation, we consider the oxygen fractionation factor between dissolved sulfate and water of Zeebe (2010) similar to that of Hałas and Pluta (2000), for details see also Boschetti (2013). During calculation, we also included the precipitation effect on oxygen isotope considering a fractionation factor of approximately $3 \%$ between precipitated and dissolved sulfates (Lloyd, 1968; Szaran et al., 1998). The position of isotherms will not significantly change if we use for ${ }^{18} \mathrm{O}$ in sulfate one of the following fractionation factors: anhydrite-water (Chiba et al., 1981), alunite-jarosite-water (Stoffregen et al., 1994; Rye and Stoffregen, 1995) or barite-water (Kusakabe and Robinson, 1977). In the present case, we interpret the shift of $\delta^{18} \mathrm{O}_{\mathrm{SO} 4}$ toward higher values than these typical for marine evaporites of Permian-Triassic age resulting from partial equilibration of oxygen in sulfates with a brine, for example, this resulted from the dehydration of gypsum during the thermal overprint (Fig. 2).

\subsection{Isotopic composition of water of crystallization and brine}

The $\delta^{18} \mathrm{O}$ values of calculated brines using water of crystallization (x-axis) versus $\delta^{18} \mathrm{O}_{\mathrm{SO} 4}$ values (y-axis) are displayed in Figure 2. Gypsum and polyhalite plot in two distinct groups, with gypsum showing negative oxygen isotope values and polyhalite showing positive values of brines. Considering the measured $\delta^{18} \mathrm{O}_{\mathrm{SO} 4}$ values, the isotopic values of water of crystallisation and the isotherms presented in Figure 2, we may distinguish between several processes. Oxygen isotopic composition of gypsum shows partial equilibration of sulfate group with local brines, as their $\delta^{18} \mathrm{O}_{\mathrm{SO} 4}$ values are higher than those of the Permian marine sulfate, and this is indicated as "trend 1" (Fig. 2). Polyhalites show also a similar trend of partial equilibration between oxygen in the sulfate group with brine oxygen. A compact, fine-grained polyhalite (H_5) shows also thermal overprint, in this case at higher temperatures. The calculated value of $\sim 300{ }^{\circ} \mathrm{C}$ is too high and should be considered qualitatively, as indicating preservation of peak temperatures during the overprint event. A vein polyhalite (D_4) and a coarse crystalline polyhalite (D_2) show partial equilibration of sulfate oxygen isotopic composition with brines at temperatures between $100^{\circ}$ and $200^{\circ} \mathrm{C}$ (Fig. 2). In contrast, oxygen and hydrogen isotopic composition of brines plot on a mixing line suggesting a meteoric component (Fig. 3).

Considering the available samples, we may distinguish for polyhalite between:

- coarse polyhalite recording isotopic composition similar to evaporation brines evolving from marine water. The most enriched isotopic compositions are shown by samples NM1, NM2 (New Mexico) followed by K1 (Kłodawa Mine), sampled from evaporitic deposits, which were not deformed and thermal overprint in contrast to the evaporites of the Eastern Alps. In this frame, the samples from New Mexico and Kłodawa Mine may represent the isotopically enriched end-member of primary brines (Fig. 3);

- recrystallized orange polyhalites (D_2, H_5, D_4), which indicate either isotopic equilibration between meteoric waters and polyhalite or incorporation of meteoric waters into crystal lattice of the salt; H_5 shows an unrealistic high temperature of $\sim 300^{\circ} \mathrm{C}$, higher than polyhalite dehydration limit;

- fibrous polyhalite (HH1, A_6, H_1) formed in veins from salt rock. These samples record a latter imprint at estimated temperatures between $100^{\circ}$ and $200^{\circ} \mathrm{C}$;

- granular polyhalites grown on anhydrite or mud, which also indicate a higher temperature imprint (A_1, BI_3).

Monitoring of brines from Kłodawa Mine (Dulinski et al., 2014) has shown that enriched syngenetic water of Zechstein age is still present in closed salt pockets. The oxygen and hydrogen isotopic compositions of sygenetic brine from which Kłodawa polyhalite formed is shown in Figure 3, its composition plotting in the field of the measured brines from the salt pockets (Dulinski et al., 2014).

Permian-Triassic sulfates of Eastern Alps were thermally overprinted (Leitner et al., 2013; Bojar et al., 2016). Using illite crystallinity, vitrinite reflectance and fluid inclusions in anhydrite, Leitner et al. (2013) estimated peak overprint temperatures affecting polyhalite bearing deposits at c. $200^{\circ} \mathrm{C}$. For evaporite deposits from the Eastern Alps, Bojar et al. (2016) estimated overprint temperatures using sulfate-sulfide isotope thermometers between $190^{\circ}$ and $260^{\circ} \mathrm{C}$ (except for Tragöß gypsum deposit). As polyhalites were not thermally overprinted over $275^{\circ} \mathrm{C}$, they have preserved their water of crystallization and rather (re)crystallized at temperatures between 100 and $200{ }^{\circ} \mathrm{C}$. On the other hand, secondary growth features were found for polyhalite of the Eastern Alps (Leitner et al., 2013; Bojar et al., 2016) showing recrystallizations younger than Permian. We may assume that during a latter process partial equilibration and /or incorporation of low amount of meteoric fluid (up to $10 \%$ for the data acquired in this study) took place at temperatures closed to ambiental ones. For example, Hałas and Krouse (1982) and Kasprzyk and Jasińska, (1998) identified various amounts of meteoric water in the crystallization water of Miocene gypsum from the Carpathian realm. Tan et al. (2014) showed that isotopic compositions of Quaternary gypsum formed in Qaidam basin in an arid environment plot on a mixing line between lake brine and recharge river water.

\subsection{Relationship between the measured water of crystallization, calculated brines and local meteoric water line}

Alpine overprint temperatures over $200^{\circ} \mathrm{C}$ were high enough in order to drive dehydration of gypsum to anhydrite. Rehydration to gypsum is possible if fluids are available and temperature falls below the dehydration limit of the mineral. The calculated isotopic compositions of brine (using the oxygen and hydrogen isotopic compositions of gypsum crystallization water) indicate that during rehydration/recrys- 
tallization calcium sulfate (gypsum, anhydrite) incorporated meteoric water, as shown in Figure 2 by "trend 2". The altitudes from which gypsum samples were collected for this study range between 480 and $970 \mathrm{~m}$ (Tab. 2). Incorporated meteoric water has $\delta^{18} \mathrm{O}$ and $\delta \mathrm{D}$ values from -5.7 to $-15 \%$ and -30.9 to $-89 \%$, respectively (Fig. 3), the isotopic values do not correlate with the altitude (Tab. 2). According to Froehlich et al. (2008), for similar altitudes, weighted annual mean $\delta^{18} \mathrm{O}$ values are from -10.3 to $-10.6 \%$. These values are higher than those measured for the water of crystallization in the investigated gypsum samples. The water of crystallization for the gypsum samples is also plotting to the left of the Local Meteoric Water Line (LMWL) (Fig. 3). It has been documented that late-glacial meteoric water has lower isotopic composition than the late-Holocene one, with $\delta^{18} \mathrm{O}_{\text {late- }}$

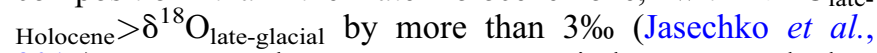
2015). Moreover, the Younger Dryas period represents the last major period of aquifer refill (Bath et al., 1979). In light of these findings, the lower isotopic values of crystallization water plotting left of the meteoric water line suggest that meteoric water was incorporated in gypsum in a period cooler and dryer than today, possible during the Younger Dryas, if not earlier. An alternative explanation could consider that gypsum crystallization water records the isotopic signature of meteoric water percolating downward from a much higher elevation than today into subsurface, thereby reaching the sulfate deposit. The incorporation of water characterized by lower isotopic values than present one was put in evidence also for Miocene sulfates (Hałas and Krouse, 1982). In Figure 3, gypsum samples from the halite type deposits, HT_2, H_4, A_5 (all transparent gypsum crystals, see supplementary material) show an isotopic composition of crystallization water close to the present global meteoric water line, suggesting late crystal growth.

\section{Conclusions}

Polyhalite and gypsum from the Eastern Alps are of marine origin, as suggested by their sulfur isotopic composition. As the $\delta^{18} \mathrm{O}_{\mathrm{SO} 4}$ values are in the same range for gypsum and polyhalite, the thermal overprint of 100 to $200^{\circ} \mathrm{C}$ affected both minerals to similar extent.

The two minerals plot in two distinct groups (Figs. 2 and 3 ), which are not related to different precipitation stages in the marine evaporitic sequence but to different source for the incorporated crystallization water. Polyhalites from Carlsbad potash district, New Mexico and those from Kłodawa Mine (Poland) preserve an enriched syngenetic isotopic composition, characteristic for brines evolving from marine water. Polyhalites from the Eastern Alps indicate a narrow range for $\delta \mathrm{D}$ and $\delta^{18} \mathrm{O}$ of syngenetic brines with enriched oxygen and hydrogen isotopic composition. For a few samples mixture with meteoric water was involved, as indicated by the shift of values toward the meteoric water line.

In the case of the Eastern Alps, the crystallization water of gypsum records incorporation of meteoric water during a later event when, related cooler conditions meteoric water was depleted in heavy isotopes. A few gypsum crystals contain crystallization water whose isotopic compositions $(\delta \mathrm{D}$ and $\left.\delta^{18} \mathrm{O}\right)$ are close to those of the present-day MWL.
Acknowledgments. The authors would like to thank to Stefan Nicolescu (Yale Peabody Museum of Natural History) for providing a polyhalite sample from New Mexico. We thank native speakers for checking the text. Christophe Lécuyer and Tiziano Boschetti are thanked for interesting comments and suggestions. An anonymous reviewer is thanked as well. An English native speaker checked the text.

We acknowledge CEEPUS mobility grant for Ana-Voica Bojar, facilitating cooperation with Mass Spectrometry Laboratory, Institute of Physics, Maria Curie-Skłodowska University, Lublin.

\section{References}

Armstrong G, Dunham KC, Harvey CO, Sabine PA, Waters WF. 1951. The paragenesis of sylvine, carnallite, polyhalite and kieserite in Eskdale borings nos. 3,4, and 6, northe-east Yorkshire. Mineralogical Magazine XXIX: 667-690.

Barker JM, Austin GS. 1993. Economic geology of the Carlsbad potash district, New Mexico. In: Love DW, Hawley JW, Kues BS, Austin GS, Lucas SG, eds. New Mexico Geological Society $44^{\text {th }}$ Annual Fall Field Conference Guidebook. Carlsbad Region (New Mexico and West Texas: $357 \mathrm{p}$.

Barrer RM, Denny AF. 1964. Water in hydrates. Part I. Fractionation of hydrogen isotopes by crystallization of salt hydrates. Journal of the Chemical Society 4677-4684. DOI: 10.1039/JR9640004677.

Bath AH, et al. 1979. Paleoclimatic trends deduced from the hydrochemistry of a Triassic Sandstone aquifer, U.K. In: Isotope Hydrology 1978, Vol. II. IAEA, pp. 545-568.

Bojar A-V, Halas S, Bojar A-V, Chmiel S. 2017. Stable isotope hydrology of precipitation and groundwater of a region with high continentality, South Carpathians, Romania. Carpathian Journal of Earth and Environmental Sciences 12(2): 513-524.

Bojar A-V, Hałas S, Bojar H-P, Trembaczowski A. 2016. Late Permian to Triassic isotope composition of sulfates in the Eastern Alps: palaeogeographic implications. Geological Magazine. DOI: 10.1017/S0016756816000996.

Boschetti T. 2013. Oxygen isotope equilibrium in sulfate-water systems: a revision of geothermometric applications in lowenthalpy systems. Journal of Geochemical Exploration 124: 92 100. DOI: 10.1016/j.gexplo.2012.08.011.

Boschetti T, Cortecci G, Toscani L, Iacumin P. 2011. Sulfur and oxygen isotope compositions of Upper Triassic sulfates from northern Apennines (Italy): paleogeographic and hydrogeochemical implications. Geologica Acta 9: 129-147.

Burliga S. 2014. Heterogeneity of folding in Zechstein (Upper Permian) salt de posits in the Kłodawa Salt Structure, central Poland. Geological Quarterly 58(3): 565-576.

Camur MZ, Mutulu H. 1996. Major-ion geochemistry and mineralogy of the Salt Lake (Tuz GöSliü) basin, Turkey. Chemical Geology 127: $313-329$.

Chako T, Cole DR, Horita J. 2001. Equilibrium oxygen hydrogen and carbon isotope fractionation factors applicable to geologic systems. In: Valley JW, Cole DR, eds. Stable Isotope Geochemistry. Reviews in Mineralogy and Geochemistry 43: 1-81.

Chiba, H., Kusakabe M, Hirano S-I, Matsuo S, Shigeyuki S. 1981. Oxygen isotope fractionation factors between anhydrite and water from 100 to $550{ }^{\circ} \mathrm{C}$. Earth and Planetary Science Letters 53: 55-62.

Chiba H, Sakai H. 1985. Oxygen isotopic exchange rate between dissolved sulfate and water at hydrothermal temperatures. Geochimica et Cosmochimica Acta 48: 993-1000. 
Claypool GE, Holser WT, Kaplan IR, Sakai H, Zak I. 1980. The age curves of sulfur and oxygen isotopes in marine sulfate and their mutual interpretation. Chemical Geology 28: 199-260.

D'Ans J. 1908. Über Caesium-dicalcium-sulfat. Chemische Berichte 41/2: 1777-1779.

Dulinski M, Rózanski K, Brudnik K, Kolonko P, Tadych J. 2014. Isotope monitoring of water appearances in salt mines: The Polish experience. Radioactive Waste Management Committee Natural Analogues for Safety Cases of Repositories in Rock Salt "Salt Club" Workshop Proceedings. pp. 123-132.

Fisher S, Voigt W, Köhnke K. 1996. The thermal decomposition of polyhalite $\mathrm{K}_{2} \mathrm{SO}_{4}-\mathrm{MgSO}_{4}-2 \mathrm{CaSO}_{4}-2 \mathrm{H}_{2} \mathrm{O}$. Cryst. Res. Tehnol. 31/1: 87-92.

Fontes JC, Gonfiantini R. 1967. Fractionment isotopique de l'hydrogene dans ĺeau de crystallization du gypse. Comptes Rendue de l'Académie des Sciences. Paris: 265, pp. 2-4.

Froehlich K, Kralik M, Papesch W, Rank D, Scheifinger H, Stichler W. 2008. Deuterium excess in precipitation of Alpine regions moisture recycling. Isotopes in Environmental and Health Studies 44/1: 1-10.

Gazquez F, Evans NP, Hodell DA. 2017. Precise and accurate isotope fractionation factors $\left(\alpha^{17} \mathrm{O}, \alpha^{18} \mathrm{O}\right.$ and $\left.\alpha \mathrm{D}\right)$ for water and $\mathrm{CaSO}_{4} * 2 \mathrm{H}_{2} \mathrm{O}$ (gypsum). Geochimica et Cosmochimica Acta 198: 259-270.

Gonfianti R, Fontes JC. 1963. Oxygen isotopic fractionation in the water of crystallization of gypsum. Nature 2000: 644-646.

Hałas S, Bojar A-V, Peryt TM. 2015. Oxygen isotopes in authigenic quartz from massive salt deposits. Chemical Geology 402: 1-5.

Hałas S, Krouse HR. 1982. Isotopic abundances of water of crystallization of gypsum from the Miocene evaporite formation, Carpathian Foredeep, Poland. Geochimica et Cosmochimica Acta 46: 293-296.

Hałas S, Pluta I. 2000. Empirical calibration of isotope thermometer $\delta^{18} \mathrm{O}\left(\mathrm{SO}_{4}{ }^{2-}\right)-\delta^{18} \mathrm{O}\left(\mathrm{H}_{2} \mathrm{O}\right)$ for low temperature brines. Kraków, Poland: V Isotope Workshop of the European Society for Isotope Research: 68-71.

Hałas S, Szaran J. 2001. Improved thermal decomposition of sulfates to $\mathrm{SO}_{2}$ and mass spectrometric determination of $834 \mathrm{~S}$ of IAEA SO5, IAEA SO-6 and NBS-127 sulfate standards. Rapid Communications in Mass Spectrometry 15: 1618-1620.

Hałas S, Szaran J, Czarnacki M, Tanweer A. 2007. Refinements in $\mathrm{BaSO}_{4}$ to $\mathrm{CO}_{2}$ preparation and $\delta^{18} \mathrm{O}$ calibration of the sulphate standards NBS-127, IAEA SO-5 and IAEA SO-6. Geostandard Geoanalytical Research 31: 61-68.

Hardie LA. 1996. Secular variation in seawater chemistry: an explanation for the coupled variation in the mineralogies of marine limestones and potash evaporites over the past $600 \mathrm{my}$. Geology 24: 279-283.

Herwartz D, Surma J, Voigt C, Assonov S, Staubwasser M. 2017. Triple oxygen isotope systematics of structurally bonded water in gypsum. Geochimica et Cosmochimica Acta 209: 254-266.

Holser WT. 1966. Diagenetic polyhalite in recent salt from Baja California. The American Mineralogist 51: 99-109.

Holland HD. 1984. The Chemical Evolution of the Atmosphere and Oceans. Princeton, NJ: Princeton University Press, 582 p.

Horita J. 1989. Stable isotope fractionation factors of water in hydrated saline mineral-brine system. Earth and Planetary Science Letters 95: 173-179.

IAEA/WMO, 2010. Global Network of Isotopes in Precipitation: The GNIP Database, available at: http://www.iaea.org/water (last access: 20 June 2017).
Jasechko S, Lechler A, Pausata FSR, Fawcett PJ, Gleeson T, Cendón DI, Galewsky J, LeGrande AN, Risi C, Sharp ZD, Welker JM, Werner M, Yoshimura K. 2015. Late-glacial to late-Holocene shifts in global precipitation. Climate of the Past 11: 1375-1393.

Kampschulte A, Buhl D, Strauss H. 1998. The sulfur and strontium isotopic compositions of Permian evaporates from the Zechstein basin, northern Germany. Geologische Rundschau 87: 192-199.

Kasprzyk A, Jasińska B. 1998. Isotopic composition of the crystallization water of gypsum in the Badenian of the northern Carpathian Foredeep: a case study from the cores Przyborow 1 and Strzegom 143. Geological Quarterly 42/3: 301-310.

Kemp SJ, Smith FW, Wagner D, Mounteney I, Bell CP, Milne CJ, Gowing CJB, Pottas TL. 2016. An improved approach to characterize potash-bearing evaporite deposits, evidenced in North Yorkshire, United Kingdom. Economic Geology 111: 719-742.

Kemp BR, ed. 1999. Handbook of Thermal Analysis and Calorimetry, Vol. 4, From Macromolecules to Man. Elsevier, 1032 pp.

Knauth LP, Beeunas MA. 1986. Isotope geochemistry of fluid inclusions in Permian halite with implications for the isotopic history of ocean water and the origin of saline formation waters. Geochimica et Cosmochimica Acta 50/3: 419-433.

Kusakabe M, Robinson BW. 1977. Oxygen and sulfur isotope equilibria in the $\mathrm{BaSO}_{4}{ }^{-}-\mathrm{HSO}_{4}{ }^{-}-\mathrm{H}_{2} \mathrm{O}$ system from 110 to $350{ }^{\circ} \mathrm{C}$ with applications. Geochimica et Cosmochimica Acta 41: 1033 11040.

Leitner C, Neubauer F, Genser J, Borojevic-Sostaric B, Rantitsch G. 2013. ${ }^{40} \mathrm{Ar} /{ }^{39} \mathrm{Ar}$ ages of recrystallization of rock-forming polyhalite in Alpine rocksalt deposits. In: Jordan F, Mark DF, Verati C, eds. Advances in ${ }^{40} \mathrm{Ar}{ }^{\beta 9} \mathrm{Ar}$ Dating: from Archaeology to Planetary Sciences. Geological Society, London, Special Publications, 378, 207-244.

Lloyd RM. 1968. Oxygen isotope behaviour in the sulfate-water system. Journal of Geophysical Research 73/18: 6099-6110.

Longinelli A. 1983. Oxygen-18 and sulphur-34 in dissolved oceanic sulphate and phosphate. In: Fritz P, Fonts JC, eds. The Marine Environment. Handbook Environ. Isotope Geochem. Amsterdam: Elsevier: 219-255.

Longinelli A, Flora O. 2007. Isotopic composition of gypsum samples of Permian and Triassic age from the north-eastern Italian Alps: Palaeoenvironmental implications. Chemical Geology, 245/3-4: 275-284.

Lowenstein TK. 1988. Origin of depositional cycles in the Permian "saline giant": the Salado (McNutt zone) evaporites of New Mexico and Texas. Geological Society of America Bulletin 100: 592-608.

Lowenstein TK, Spencer RJ, Pengxi Z. 1989. Origin of ancient potash evaporites: clues from the modern nonmarine Qaidam Basin of western China. Science 245: 1090-1092.

Ma L, Lowenstein TL, Li B, Jiang P, Liu C, Zhong J, Sheng J, Qiu H, Wu H. 2010. Hydrochemical characteristics and brine evolution paths of Lop Nor Basin, Xinjiang Province, Western China. Applied Geochemistry 25: 1770-1782.

Matsubaya O, Sakai H. 1973. Oxygen and hydrogen isotopic study on the water of crystallization of gypsum from the Kuroko type mineralization. Geochemical Journal 7: 153-165.

Paytan A, Gray E. 2012. Sulfur isotope stratigraphy. A geological time scale. In: Gradstein F, et al., eds. In: The Geologic Time Scale, Vol. 1. Elsevier: 161-180. Chapter 9.

Pena JA, Garcia-Ruiz JM, Marfil R, Prieto M. 1982. Growth features of magnesium and sodium salts in a recent Playa Lac of La Mancha (Spain). Estudios geol. 38: 245-257. 
Peryt TM, Pierre C, Gryniv SP. 1998. Origin of polyhalite deposits in Zechstein (Upper Permian) Zdrada platform (northern Poland). Sedimentology 45: 565-578.

Peryt TM, Tomassi-Morawiec H, Czapowski G, Hryniv SP, Pueyo JJ, Eastoe CJ, Vovnyuk S. 2005. Polyhalite occurrence in the Werra (Zechstein, Upper Permian) Peribaltic Basin of Poland and Russia: Evaporite Facies Constraints. Carbonates and Evaporites 20(2): 182-194.

Rye RO, Stoffregen RE. 1995. Jarosite-water oxygen and hydrogen isotope fractionation: preliminary experimental data. Economic Geology 90: 2336-2342.

Schorn A, Neubauer F, Bernroider M. 2013. Polyhalite microfabrics in an Alpine evaporite mélange : Hallstatt, Eastern Alps. Journal of Structural Geology 46: 57-75.

Seal RR II, Alpers CN, Rye RO. 2000. Stable isotope systematics of sulfate minerals. In: Alpers, C.N., Jambor, J.L., Nordstrom, D.K., (eds.). Sulfate minerals, crystallography, geochemistry and environmental significance. Reviews in Mineralogy \& Geochemistry 40: 541-602.

Sial AN, Gaucher C, Ferreira VP, Pereira NS, Cezario WS, Chiglino L, Lima HM. 2015. Isotope and elemental chemostratigraphy. In: Chemostratigraphy. Elsevier: 23-64. Chapter 2.
Sinha R, Raymahashay BC. 2004. Evaporite mineralogy and geochemical evolution of the Sambhar Salt Lake, Rajasthan, India. Sedimentary Geology 166: 59-71.

Stoffregen RE, Rye RO, Wasserman MD. 1994. Experimental studies on alunite: I. ${ }^{18-16} \mathrm{O}$ and D-H fractionation factors between alunite and water at $250^{\circ}-450^{\circ} \mathrm{C}$. Geochimica et Cosmochimica Acta 58: 903-916.

Szaran J, Niezgoda H, Hałas S. 1998. New determination of oxygen and sulphur isotope fractionation between gypsum and dissolved sulphate. ESIR Isotope Workshop IV, Portorož, June 1998. RMZ Materials and Geoenvironment 45: $180-182$.

Tan H-B, Huang J-Z, Zhang W-J, Liu X-Q, Zhang Y-F, Kong N, Zhang Q. 2014. Fractionation of hydrogen and oxygen isotopes of gypsum hydration water and assessment of its geochemical indications. Australian Journal of Earth Sciences 61 (6): 793-801.

Wollmann G, Freyer D, Voigt W. 2008. Polyhalite and its analogous triple salts. Monatshefte für Chemie 139: 739-745.

Zeebe RE. 2010. A new value for the stable oxygen isotope fractionation between dissolved sulfate ion and water. Geochimica et Cosmochimica Acta 74: 818-828.

Cite this article as: Bojar A-V, Hałas S, Bojar H-P, Trembaczowski A. 2019. Multiple isotope tracers from Permian-Triassic hydrated sulfates: Implications for fluid-mineral interaction, BSGF - Earth Sciences Bulletin 190: 11. 